\title{
Molecular Identification of a Fungal Pathogen Batrachochytrium dendrobatidis and Its Impact on Urbanized New Jersey
}

\author{
Tin-Chun Chu1, Meiyin Wu², Lauren Pohren¹, Bobak Haghjoo², Christina Soman², Lee H. Lee² \\ ${ }^{1}$ Department of Biological Sciences, Seton Hall University, New Jersey, USA \\ ${ }^{2}$ Department of Biology \& Molecular Biology, Montclair State University, New Jersey, USA \\ Email: tin-chun.chu@shu.edu
}

Received 15 October 2014; revised 17 November 2014; accepted 26 November 2014

Copyright (C) 2014 by authors and Scientific Research Publishing Inc.

This work is licensed under the Creative Commons Attribution International License (CC BY).

http://creativecommons.org/licenses/by/4.0/

c) (i) Open Access

\begin{abstract}
In urban landscape, amphibians face many challenges in order to sustain their populations, such as road mortality and infection of pathogenic Batrachochytrium dendrobatidis (Bd). Bd infection has been reported to cause significant mortality; however, its current distribution in the state of New Jersey remains unknown. In spring, amphibians emerge from their wintering group and migrate to nearby breeding ponds or vernal pools. Their migration pathway is often intercepted by the dense network of human transportation which leads to extirpation. This study aims to investigate potential mortality caused by human transportation and the infected rate of Bd fungus on the amphibian populations at a suburban area in central New Jersey. Twenty-four pitfall traps were installed to collect amphibians. A total of 687 organisms representing 7 amphibian species were recorded during the 73-day study period. Four of the 7 species were selected to test for Bd infection; $73.6 \%$ of the amphibian skin swabs showed positive results of infection. However, Bd was not detected in water and soil samples collected around the study areas. The results of this study suggested that road mortality and pathogenic Bd might have tremendously impacted the urban amphibian populations and might have been the major causes of the current trend of amphibian population decline, particularly in the urban area.
\end{abstract}

Keywords

Amphibian, Habitat Fragmentation, Batrachochytrium dendrobatidis, Bd, Habitat Connectivity

\section{Introduction}

The declination in global trends of amphibian populations is one of the most obscure environmental problems

How to cite this paper: Chu, T.-C., Wu, M.Y., Pohren, L., Haghjoo, B., Soman, C. and Lee, L.H. (2014) Molecular Identification of a Fungal Pathogen Batrachochytrium dendrobatidis and Its Impact on Urbanized New Jersey. Advances in Microbiology, 4, 1164-1173. http://dx.doi.org/10.4236/aim.2014.416126 
that scientists and wildlife face today [1]. Wetland habitats provide food, shelter and substrate for amphibians and act as keystone ecosystems enabling amphibians to complete their life cycles. However, worldwide wetlands are being destroyed and/or lost at an alarming rate; approximately $50 \%$ of global wetland area has been lost primarily due to human activities [2]. In the United States, $53 \%$ of all historical wetlands in the lower 48 states have been destroyed by anthropogenic causes, such as urban development, agriculture activities, hydrological alteration, water pollution [3], etc. The reliance of amphibians on those habitats makes them vulnerable to the current trends of degradation and loss of wetlands around the globe [4]. Another threat to wetland ecosystems is global climate change accelerating the rates of wetland degradation and loss [5]. Global climate change has been documented to affect temperature, humidity, evaporation, transpiration, precipitation, and the rate of sea level rise [6] [7]. Those changes in climate patterns are likely to cause many wetland ecosystems to experience changes in its freshwater inflow and water balance; it is likely to dramatically affect seasonal vernal pool wetlands, particularly at the lower latitudes. Vernal pools at the arid area might disappear as a result of an increase in temperature and a decline in precipitation.

At the landscape level, habitat loss and fragmentation are major threats to amphibians. Humans have dominated most of these regions in Northern landscapes and most evident, the succession of building complex networks of roadways for ease of the transportation amongst passengers, consumables, and other goods. Today, in the United States alone, this network extends for approximately 4 million miles covering approximately $1 \%$ of total land area and was used by about a quarter billion vehicles [8] [9]. This trend of urbanization and its impacts on habitat fragmentation and loss are expected to continue into the future [10]. These roads cut through urban area, industrial parks, tropical forests, flood plains and tidal salt marshes, etc. While transporting human and goods to their destination, roads fragmented natural habitats at the expenses of wildlife species which depend on those habitats to survive [11]. Forman (2000) estimated $20 \%$ of the land area in the conterminous U.S. was under impacted ecologically by the network of roadways and traffic. Habitat degradation, fragmentation, loss, and isolation caused by human transportation have become one of the major pressures driving species extinction and endangerment [11] [12].

In early spring, amphibians emerge from their wintering ground in the upland forests and migrate up to 3000 meters to nearby ponds and pools including vernal pools to feed, mate and breed [4] [13] [14]. Their migration pathways often are intersected by human transportation roadways. Many studies documented high mortality rates of amphibian species along these crossways during the spring migration season, both pre- and post-breeding; mortality along roadways could detrimentally impact the continuation of amphibian populations [4] [11] [12] [15]-[19]. Mortality rates were also reported to be increasingly correlated with traffic volume [4] [20].

While the complex network of roadways transports passengers, consumables, and other goods, it also transports pathogens, alongside other contaminants, which poses an immense challenge for amphibian populations in their new and altered landscapes [11]. Fewer breeding habitats due to fragmentation and loss might have further limited the dispersal and migration movement of amphibians and caused populations to concentrate within the limited available living space, which further results in an increase in the spread of pathogens both intraspecies and interspecies. Batrachochytrium dendrobatidis (Bd), a chytrid fungus, infects the keratinized tissue of amphibians and causes chytridiomycosis. The disease has drawn attentions of herpetologists globally due to its high mortality rates and its wide range of distribution, found in Australia, Central and South America and part of North America. Although this disease is often fatal, its mechanism remains unknown [21]. In the past few years, Bd has spread to the east coast of United States from Maine to Rhode Island [22]. To date, Bd has infected more than 350 amphibian species and has claimed to be responsible for the decline of over 200 species [23]. It has been considered as one of the most destructive emerging diseases worldwide [1] [24] [25]. Garner et al. (2009) reported approximately $50 \%$ of all amphibian species were threaten with extinction worldwide. Many were due to a combination of habitat loss, pathogens as well as global climate change [26].

This study aims to investigate challenges faced by amphibians on urban landscapes in today's changing world with special focuses on potential impacts caused by human transportation and pathogen, Batrachochytrium dendrobatidis. Potential mortality caused by human transportation and infected rate of $\mathrm{Bd}$ fungus on the amphibian populations were observed at a suburban area in central New Jersey.

\section{Material and Methods}

\subsection{Site Description}

This study was conducted at River Road Park at Bedminster, NJ (40.662223-74.646626). River Road, a busy 
commuter route, cuts through the park. The River Road Park includes over 300 acres of preserved open space for passive recreation and the 183 acre Stahl Natural Area, a nature preserve. The southern side of the road offers mature forested habitats and riparian habitats along the North Branch of the Raritan River. The forest is dominated by red hickory, red maple, spruce, black cherry, white oak, red oak, American elm, Japanese barberry, etc. The northern side of the road is grassland with two ponds hidden behind the tall grasses. This grassland is an important bird nesting area of the region housing species including Grasshopper Sparrow, Savannah Sparrow, Eastern Meadowlark, Bobolink, and Northern Harrier [27]. This diverse grassland habitat has been actively managed through mowing and brush-hogging since 2004 partially funded by the Wildlife Habitat Incentives Program from the US Department of Agriculture Natural Resource Conservation Service. During the spring migration season, pool-breeding amphibians leave their wintering ground in the forested habitat at the southern side of the road and migrate to the two ponds at the northern side of the road.

\subsection{Pool-Used Amphibians' Populations Estimation}

A 185 -meter transect line was placed parallel with the roadway at approximately 5 meters from River Road in the forested habitat (Figure 1). Silt fence was placed along the transect line to present organisms crossing. Twenty-four 19-Liter buckets were used as the pitfall traps to collect amphibians. The traps were spaced equally across the transect at approximately 8 meters apart and buried with about 5 centimeters of the bucket exposed with a soil ramp around the edge of the bucket. Organisms found in the traps were recorded twice a day at 12-hour intervals between March 14 and May 26. Excess dirt and debris were removed from the trap daily and the amount of water in each trap was recorded. Daily temperature and precipitation data were obtained from the New Jersey Weather and Climate Network.

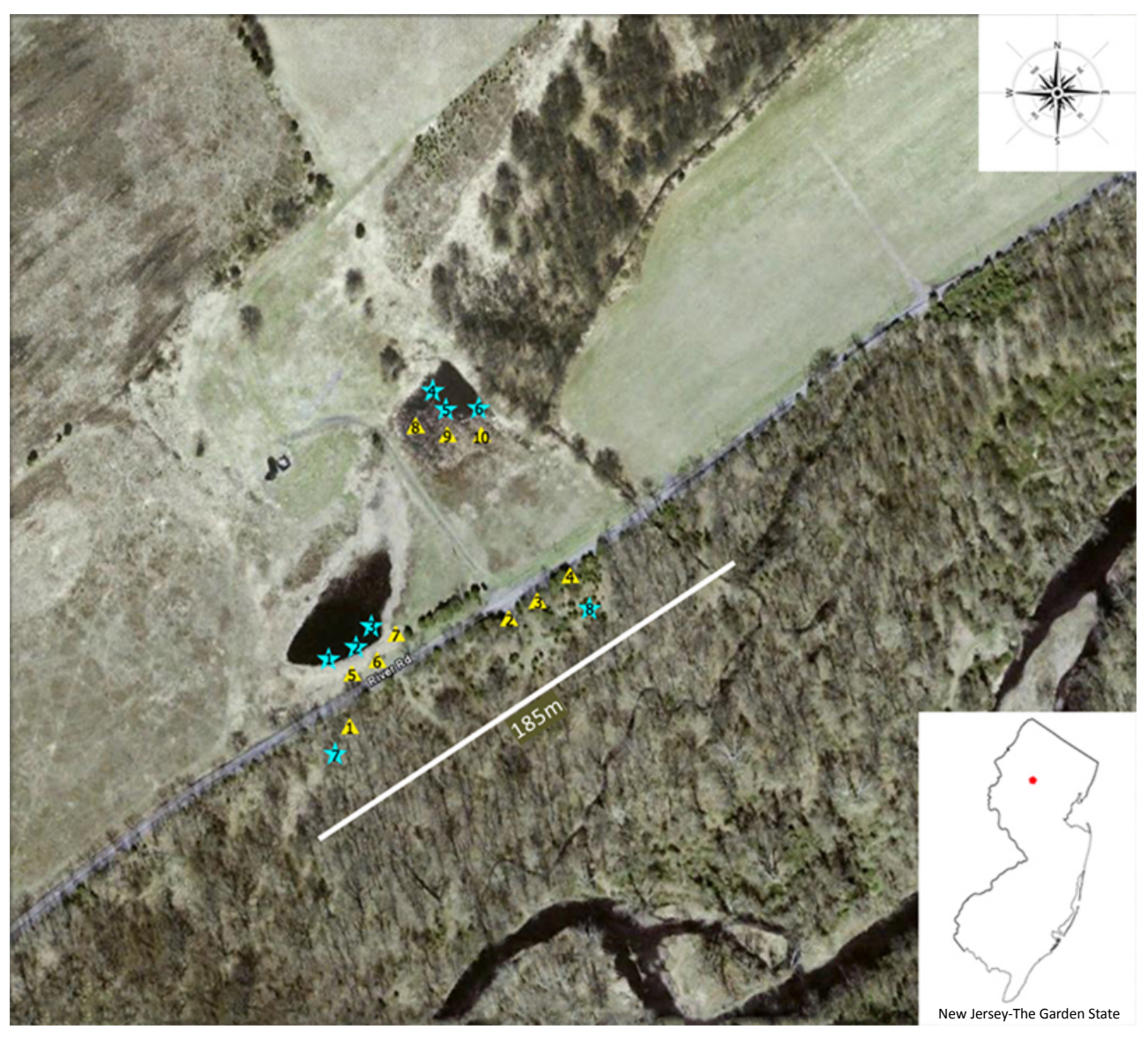

Figure 1. An aerial view of the study site located at Stahl Natural Area, Bedminster, NJ. The line marked the location of the 185-meter transect line where 24 pitfall traps were installed. The blue stars marked the locations for water sample collection, and yellow triangles for soil samples. 


\subsection{Amphibian Skin Swab Samples}

Individuals of four dominant amphibians species, American Toad (Bufo americanis), Green Frog (Rana clamitans), Northern Grey Tree Frog (Hyla versicolor), and Spring Peeper (Pseudacris crucifer), caught in the traps were randomly selected and tested for infection of Batrachochytrium dendrobatidis. Sterile cotton swabs were used to swab firmly on the belly skin for 25 times. Ventral area of focus with appendages as well with a total area of roughly $5-6 \mathrm{~cm} \times 5-6 \mathrm{~cm}$ and then placed in $1 \mathrm{ml} 70 \%$ ethanol in sterile microfuge tubes. The excess stick of the swab was cutoff to submerge the cotton tip completely into ethanol. The samples were labeled and stored at $-20^{\circ} \mathrm{C}$ prior to processing $[28]$.

\subsection{Soil and Water Samples}

At the last collection date, we also collected soil and water samples from the region. Ten soil samples were collected along the transect lines and on the migration pathway (Figure 1). Eight water samples were collected from the two breeding ponds and the two creeks bordering the ends of the transect line (Figure 1). Both water and soil samples were stored in sterilized glass jars, kept in ice, and immediately transported back to Seton Hall University laboratory and kept at $4^{\circ} \mathrm{C}$ for further DNA analysis for detection of $\mathrm{Bd}$.

\subsection{Batrachochytrium dendrobatidis (Bd) Cultures and DNA Extraction}

Bd culture was obtained from Dr. Joyce Longcore's lab at University of Maine. The culture was maintained in 1\% tryptone media. The DNA extract from Bd served as the positive control. Two methods were used to extract DNA from Bd culture and frog skin swabs. One was according to the methods of Longcore [29]; the other is modified chelex extraction method from Bio-Rad InstaGene ${ }^{\mathrm{TM}}$ Matrix manufacturer's protocol. The samples were retrieved from $-20^{\circ} \mathrm{C}$ freezers, centrifuged at $17,000 \mathrm{rpm}, 4^{\circ} \mathrm{C}$ for 10 minutes. The supernatants were dis-

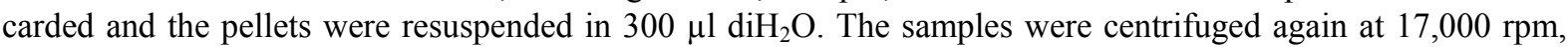
$4^{\circ} \mathrm{C}$ for 10 minutes. The supernatants were discarded and the pellets were resuspended in $200 \mu \mathrm{l}$ of Bio-Rad InstaGene ${ }^{\mathrm{TM}}$ Matrix. The samples were vortexed for 10 seconds and incubated at $56^{\circ} \mathrm{C}$ for 2 hours. After incubation, the samples were vortexed again and incubate at $100^{\circ} \mathrm{C}$ water bath for 10 minutes. Centrifugation at 10,000 rpm for 3 minutes and the supernatants were transferred into another sterile microfuge tubes. The chelex extracts were stored at $-20^{\circ} \mathrm{C}$ for PCR based assays. Water samples were collected and the DNA was isolated by using the same chelex extraction protocol. Soil samples were processed and DNA was extracted with MO BIO Ul$\operatorname{traClean}{ }^{\circledR}$ Mega Soil DNA Isolation Kit (Catalog No. 12900-10) according to the protocols described by the manufacturers.

\subsection{PCR-Based Assays}

Bd1aF (CAGTGTGCCATATGTCACG) and Bd2aR (CATGGTTCATATCTGTCCAG) primers [29] were used for all PCR-based assays. Bd1a lies in a conserved 97-bp region of the ITS1, and Bd2a is a conserved 50-bp region in the ITS2 of $B$. dendrobatidis. These regions were conserved in all of the sequenced $B$. dendrobatidis isolates.

The following PCR protocol was used: 2 minutes at $95^{\circ} \mathrm{C} / 40$ cycles of 20 seconds at $95^{\circ} \mathrm{C} ; 10 \mathrm{~s}$ at $61^{\circ} \mathrm{C} ; 10$ seconds at $70^{\circ} \mathrm{C} / 7$ minutes at $70^{\circ} \mathrm{C}$ in $20 \mu$ volumes with $1 \mu$ of template 10 (10 ng total DNA) and 10 pmol of each primer. $10 \mu$ l of Novagen ${ }^{\circledR}$ KOD Hot Start Master-Mix $(0.04 \mathrm{U} / \mu \mathrm{l})$ was used per reaction at manufacturer's standard conditions.

Sizes of the PCR products were estimated by electrophoresis on $2 \%$ agarose gel with TAE buffer. The PCR products were sequenced using GENEWIZ sequencing facility. The sequences obtained were verified by NCBI BLAST searches.

\section{Results}

\subsection{Potential Mortality of Amphibians Caused by Human Transportation}

The early spring migration typically occurs during warm wet spring nights while warm temperature signals the beginning of the breeding season and moist air and ground prevent their delicate skins from desiccating. During the 73 days of study period from March 14 to May 26, 39 days were warm and wet and with migration activities 
observed, temperature ranging from $1.11^{\circ} \mathrm{C}$ to $24.72^{\circ} \mathrm{C}$ and precipitation up to $4.4 \mathrm{~cm}$ per 24-hour period. A total of 687 organisms representing 7 amphibian species were found in the 24 pitfall traps (Table 1). The most dominant species was American Toad (Bufo americanis). A total of 469 American Toads were recorded in the traps during the study period accounted for $62.2 \%$ of total organisms. Although American Toads were frequently found in our survey traps throughout the study period, high density migration events were discovered earlier during the migration season (late March-early April). For instance, the maximum number of American Toads found during a 24-hour period was recorded at 216 with the average daily temperature of $11.11^{\circ} \mathrm{C}$ and $0.14 \mathrm{~cm}$ of precipitation on March 23. The second highest density was 108 American toads recorded at a day with similar weather condition, with an average daily temperature of $12.22^{\circ} \mathrm{C}$ and $0.54 \mathrm{~cm}$ of precipitation on April 9. On the contrary, the second most common species, Green Frog, Rana clamitans, (153, 20.29\%), tends to appear later during the migration season in May when the temperature is warmer. For instance, a total of 73 green frogs were recorded on May 23, while the average daily temperature was $18.33^{\circ} \mathrm{C}$. Other species found in the traps include Bullfrog (Rana catesbeiana), Fowler's Toad (Bufo fowleri), Northern Grey Tree Frog (Hyla versicolor), Spring Peeper (Pseudacris crucifer), and Wood Frog (Rana sylvatica) (Table 1). Other non-target organisms found in the traps include Red-spotted Newt (Notophthalmus viridescens), Spotted Salamander (Ambystoma maculatum), Red-backedSalamander (Plethodon cinereus), Common Garter Snake (Thamnophis sirtalis), Voles (Microtus spp.), and Common Snapping Turtle (Chelydra serpentine).

\subsection{Bd Detection with PCR-Based Assays}

$\mathrm{Bd} 1 \mathrm{aF}$ and Bd2aR primers were used for all PCR-based assays. The DNA extract from Bd served as the positive control. Two methods were used for DNA extraction from Bd, one is according to the method of Longcore [29]; the other is the modified chelex methods. Both methods obtained identical results and our modified chelex extraction method showed slightly better results with rapid processing time, so the chelex extraction method was used to extract DNA from all frog skin swabs and water samples.

Fifty-three samples among four different species were tested: 30 of American Toad (AT), 13 of Spring Peeper (SP), 8 of Green Frog (GF), and 6 of Northern Grey Tree Frog (NGTF). The results of PCR based assay of AT (Figure 2) indicated that $\mathrm{Bd} 1 \mathrm{aF}$ and $\mathrm{Bd} 2 \mathrm{aR}$ were able to prime the AT skin swabs and obtain a fragment with the size about 300 nucleotides that matched with the target size of approximately 296 nucleotides. Similar results were obtained from SP (Figure 3), GF and NGTF (Figure 4). The results indicated that Bd1aF and Bd2aR were able to amplify the skin samples from four collected species and their sizes matched with the target size. For the samples with multiple bands obtained from agarose gel electrophoresis, the bands with expected size approximately $300 \mathrm{bp}$ were cut, extracted and purified from the gel. The PCR products from all of the samples showed positive results and purified gel extracts were sequenced and the complete sequences were generated. The obtained sequences were then analyzed by carrying out homology Blast search and the results showed that there were $97 \%$ to $100 \%$ similarity to the reported ITS1 and ITS2 region. This study indicated that PCR successfully amplify the skin samples contain Bd.

\begin{tabular}{|c|c|c|}
\hline Amphibian Species & Number & Relative Dominance \\
\hline American Toad (Anaxyrus americanus) & 469 & $68.26 \%$ \\
\hline Green Frog (Rana clamitans) & 153 & $22.27 \%$ \\
\hline Spring Peeper (Pseudacris crucifer) & 33 & $4.80 \%$ \\
\hline Northern Grey Tree Frog (Hyla versicolor) & 27 & $3.93 \%$ \\
\hline Fowler's Toad (Bufo fowleri) & 3 & $0.43 \%$ \\
\hline Wood Frog (Rana sylvatica) & 1 & $0.14 \%$ \\
\hline Bullfrog (Rana catesbeiana or Lithobates catesbeianus) & 1 & $0.14 \%$ \\
\hline Total & 687 & $100 \%$ \\
\hline
\end{tabular}




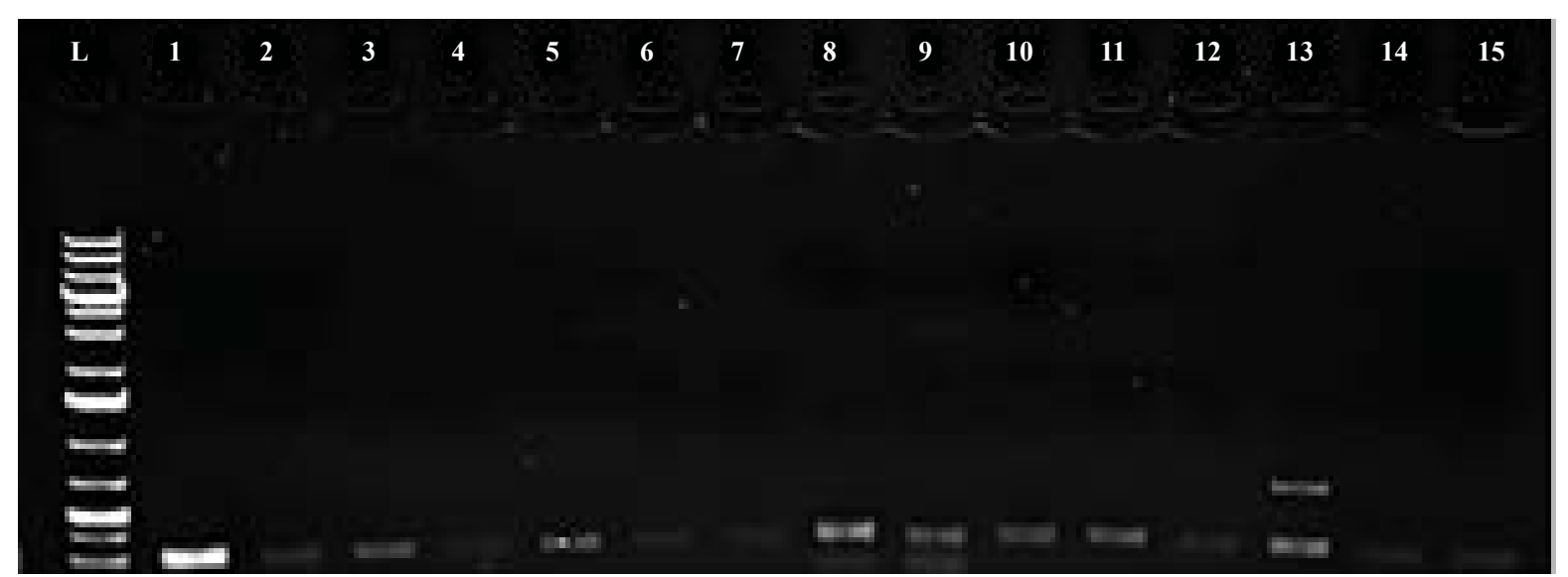

Figure 2. Gel electrophoresis result from PCR products for American Toads. Lane L: $1 \mathrm{~Kb}$ ladder; Lane 1: positive control. All 14 samples showed positive detection for Bd with the band size $\sim 296 \mathrm{nt}$.

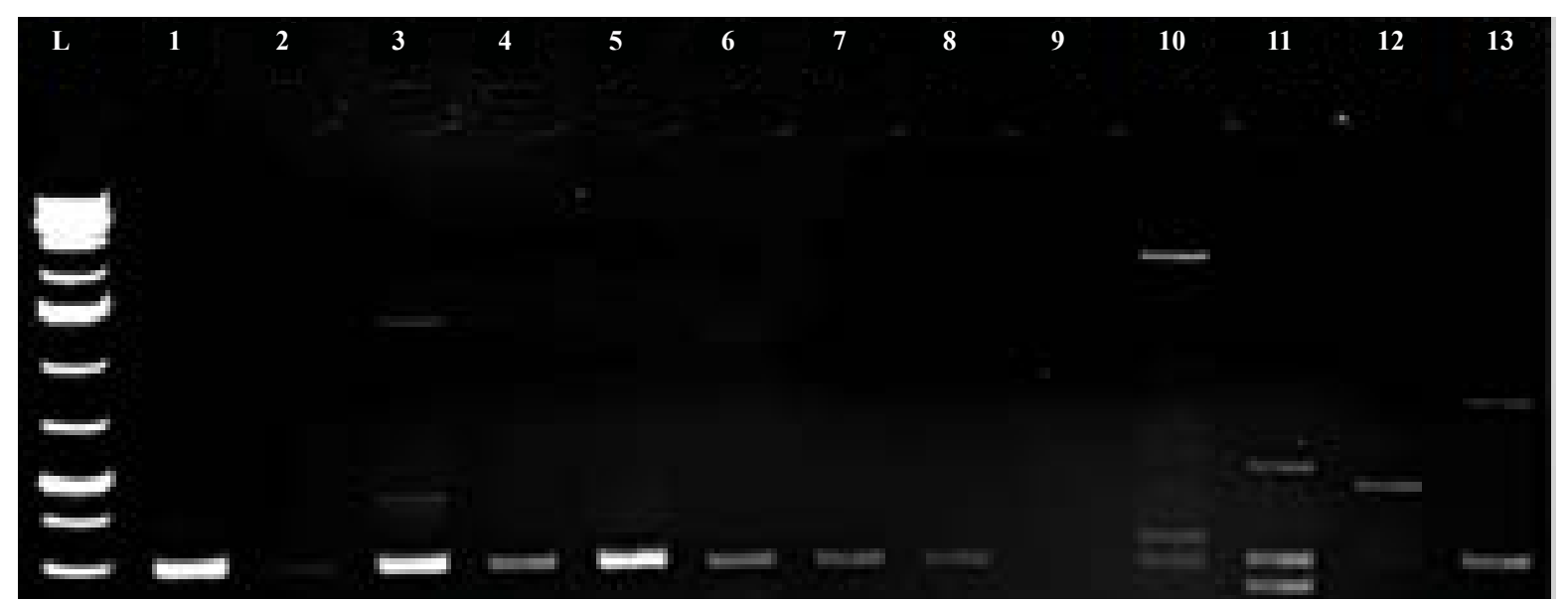

Figure 3. Gel electrophoresis result from PCR products for Spring Peepers. Lane L: $1 \mathrm{~Kb}$ ladder; Lane 1: positive control. On this gel, 9 out of 12 samples tested showed positive detection for $\mathrm{Bd}$.

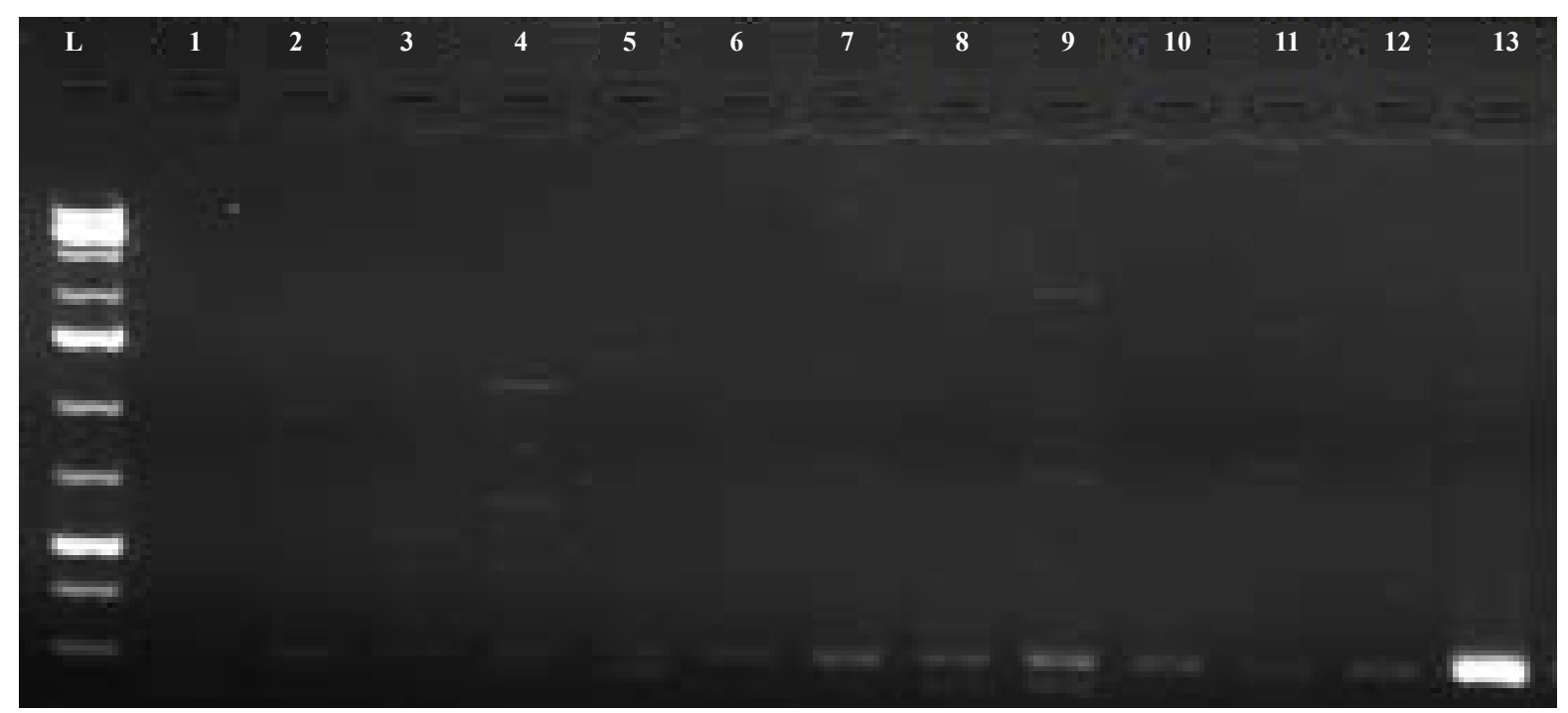

Figure 4. Gel electrophoresis result from PCR products for Green Frogs (Lanes 1 - 6) and Northern Grey (Lanes 7 - 12). Lane L: $1 \mathrm{~Kb}$ ladder; Lane 13: positive control. 
The results indicated that Bd was identified in 23 out of 30 (76.7\%) American Toads; 9 out of $11(81.8 \%)$ Spring Peepers; 2 out of 6 (33.3\%) Green Frogs; and 5 out of 6 (83.3\%) Northern Grey Tree Frogs. Overall, 73.6\% of amphibian skin swabs showed positive results (Table 2).

The PCR-based assay was also used to detect the possible existence of Bd from water and soil samples. From all these sites (ten soil and eight water sample sites), the results were all negative (not shown), suggesting that there was no detectable Bd in water and soil near the traps.

\section{Conclusions}

Batrachochytrium dendrobatidis $(\mathrm{Bd})$ has been identified and reported to spread between the amphibians and further caused significant amphibian mortality. The complete pathogenesis of Bd that leads to mortality in amphibians is being actively studied to fully understand the process. It is suggested that environment factors such as temperature, $\mathrm{pH}$, and varies strengths of $\mathrm{Bd}$ virulence play a role in the infection of various species. In this study, the results suggested that urban landscaping could also be a major contributor for emerging of Bd. There are many other reported amphibian pathogens such as ranavirus, leukocyte virus, abrovirus, sanbis virus, some gram negative bacteria Chlamydia, Mycobacterial and Aeromonas hydrophila, Microsporidia, trypanosomes, some pathogenic helminthes and arthropods. Among these pathogens, ranavirus has gained global attention on its emerging damage and it poses a huge threat on natural population of amphibian [30] [31]. Future studies, both $\mathrm{Bd}$ and ranavirus should be identified simultaneously for the collecting samples. Although other pathogens do not have large impact on amphibians, climate change and human activities may favored the growth of these pathogens and cause more problems globally in the future. More monitoring and sensitive detection methods should be established.

Although the global transmission route of Bd remains unknown, previous reports suggest it may involve in a number of approaches including human activities, physical contact among animals and contaminated water [32]. Previous reports suggested Bd can be spread by physical contact among frogs or through water [32]. In this study, focused on the northern New Jersey sites, no detectable Bd in any of the water and soil sample was found. The study suggested that soil and water of those sites are not contaminated or Bd present in an under detectable range.

Many methods have been developed to identify Bd on amphibians such as histological and histochemical analysis, PCR and qPCR based assay. In order to carry out PCR based assay, different DNA extraction methods were also reported [29] [32]. Two methods were used at the beginning of this study for both Bd and some skin swabs. The results were similar but the modified chelex method is easier, cheaper, and faster with higher yield. Therefore, in this study, the modified chelex method was used to extract DNA from the amphibian skin swabs followed by PCR-based assays for Bd detection. This method can be used in the future to identify Bd in different areas. This study is to detect the presence of Bd. Further study is needed to determine the infection intensity by using real-time PCR to obtain quantitative data.

The total number of amphibians crossing the 185-meter segment of the River Road during the study period was suspected to be higher than the reported number above. Although silt fences were placed to guide organisms to the pitfall traps and to block organisms from entering the roadways, we documented several incidents of insecure silt fence caused by strong winds during the study period. Some organisms might have escaped from the insecure fence and migrated out of the forested area without being accounted for. Another possible reason to impact the accuracy of the population estimate is predation. A reservation towards the use of pitfall traps/silt fence in amphibian studies was that pitfall traps might become death traps for amphibians and convenient locations for predators to collect the prey.

Table 2. PCR results from 53 tested amphibians in 4 species.

\begin{tabular}{ccccc}
\hline Amphibian species & Sample size & Positive & Negative & $\%$ infested \\
\hline American Toad & 30 & 23 & 7 & $76.67 \%$ \\
Spring Peeper & 11 & 9 & 2 & $81.8 \%$ \\
Green Frog & 6 & 2 & 4 & $33.33 \%$ \\
Northern Grey Tree Frog & 6 & 5 & 1 & $83.3 \%$ \\
\hline
\end{tabular}


In this study, a wildlife camera was placed along the pitfall traps to observe predation activities if any. We recorded wildlife activities, such as deer checking out the traps and a black bear visiting the area without disturbing the traps. There was no record of predation against organisms caught in traps during the study period.

After data collection, all organisms were immediately transported by trained project personnel across the road and released onto the grassland at the northern side of the road where two breeding ponds are located in order to avoid mortality caused by vehicles on the roadway. The New Jersey Department of Transportation (DOT) Division of Traffic Engineering and Safety actively surveyed and maintained traffic volume data. Based on DOT's survey result, an average of 450 vehicles pass the 2-way River Road during a 24-hour period (NYSDOT, unpublished data). Since the probability that an organism would be killed as it attempted to cross a road, $P_{\text {killed }}$, is positively correlated with traffic volume, the following formula was used to estimate the potential mortality [20]:

$$
P_{\text {killed }}=1.537 * \text { vehicles } / \mathrm{min}-0.0048
$$

Based on the traffic volume of 450 vehicles, the probability of killed, $P_{\text {killed, }}$ at the study site was estimated to be 0.4755 . The result suggested that, during the 10 -week study period, human transportation had a potential to impact 368 amphibians within an approximately 185 -meter segment of this two-lane roadway in a New Jersey suburban area.

Amphibians are likely to be particularly vulnerable toward the current trend of habitat loss due to its unique life history pattern of migrating from wintering ground in the upland forests to breeding vernal pools in spring. This study surveyed amphibian populations utilizing a short segment of a commuter road in central New Jersey as a part of amphibian's spring migration pathway. A total of 687 frogs in 7 species were found in the 24 pitfall traps along the River Road during the study period. Among the four abundant species of total 53 frogs tested, $73.6 \%$ of the amphibian skin swabs showed positive results of Bd infection. However, Bd was not detected in water and soil samples collected nearby the study areas. The results suggested pathogenic Bd might have tremendously impacted the urban amphibian populations and might have been the major causes of the current trend of amphibian population decline, particularly in the urban area.

\section{Acknowledgements}

The authors thank the landowner-Bedminster Township, Mrs. Gretchen Fowles and Mr. Brian Zarate of the New Jersey Department of Environmental Protection, Ms. Kimberly Hatch of the Bedminster's Open SpaceFarmland Preservation Committee, and Ms. McKenzie Hall of the Conserve Wildlife Foundation of New Jersey. Special thanks to all students at Biology and Molecular Biology Department at Montclair State University who participated in the field work. This project was supported by the following funding sources: Seton Hall University Biological Sciences Research Fund, Clare BootheLuce Program Scholarship and Faculty Scholarship Program at Montclair State University.

\section{References}

[1] Daszak, P., Berger, L., Cunningham, A.A., Hyatt, A.D., Green, D.E. and Speare, R. (1999) Emerging Infectious Diseases and Amphibian Population Declines. Emerging Infectious Diseases, 5, 735-748. http://dx.doi.org/10.3201/eid0506.990601

[2] OECD (1996) Guidelines for Aid Agencies for Improved Conservation and Sustainable Use of Tropical and SubTropical Wetlands. Organization for Economic Cooperation and Development, Paris, France.

[3] Dahl, T.E. (1990) Wetlands Losses in the United States 1780's to 1980's. N.W.I.P., US Department of the Interior, Fish and Wildlife Services, Washington DC, 21.

[4] Eigenbrod, F., Hecnar, S.J. and Fahrig, L. (2008) The Relative Effects of Road Traffic and Forest Cover on Anuran Populations. Biological Conservation, 141, 35-46. http://dx.doi.org/10.1016/j.biocon.2007.08.025

[5] Erwin, K.L. (2009) Wetlands and Global Climate Change: The Role of Wetland Restoration in a Changing World. Wetlands Ecology and Management, 17, 71-84. http://dx.doi.org/10.1007/s11273-008-9119-1

[6] Houghton, J.T., Ding, Y., Griggs, D.J., Noguer, M., Van der Linden, P.J., Dai, X., Maskell, K. and Johnson, C.A., Eds. (IPCC) (2001) Climate Change 2001: The Scientific Basis. Cambridge University Press, Cambridge.

[7] Patz, J.A. and Olson, S.H. (2006) Climate Change and Health: Global to Local Influences on Disease Risk. Annals of Tropical Medicine \& Parasitology, 100, 535-549. http://dx.doi.org/10.1179/136485906X97426

[8] Forman, R.T.T. (2008) Urban Regions: Ecology and Planning Beyond the City (Cambridge Studies in Landscape 
Ecology). Cambridge University Press, Cambridge. http://dx.doi.org/10.1017/CBO9780511754982

[9] Forman, R.T.T., Sperling, D., Bissonette, J.A., Clevenger, A.P., Cutshall, C.D., Dale, V.D., Fahrig, L., France, R.L., Goldman, C.R., Heanue, K., Jones, J., Swanson, F., Turrentine, T. and Winter, T.C. (2002) Road Ecology: Science and Solutions. 2nd Edition, Island Press, Washington DC.

[10] UN-HABITAT (2004) The State of the World's Cities 2004/2005: Globalization and Urban Culture.

[11] Becker, C.G., Fonseca, C.R., Haddad, C.F.B., Batista, R.F. and Prado, P.I. (2007) Habitat Split and the Global Decline of Amphibians. Science, 318, 1775-1777. http://dx.doi.org/10.1126/science.1149374

[12] Hamer, A.J. and McDonnell, M.J. (2008) Amphibian Ecology and Conservation in the Urbanizing World: A Review. Biological Conservation, 141, 2432-2449. http://dx.doi.org/10.1016/j.biocon.2008.07.020

[13] Cushman, S.A. (2006) Effects of Habitat Loss and Fragmentation on Amphibians: A Review and Prospectus. Biological Conservation, 128, 231-240. http://dx.doi.org/10.1016/j.biocon.2005.09.031

[14] Houlahan, J.E., Keddy, P.A., Makkay, K. and Findlay, C.S. (2006) The Effects of Adjacent Land Use on Wetland Species Richness and Community Composition. Wetlands, 26, 79-96. http://dx.doi.org/10.1672/0277-5212(2006)26[79:TEOALU]2.0.CO;2

[15] Ashley, E.P. and Robinson, J.T. (1996) Road Mortality of Amphibians, Reptiles and Other Wildlife on the Long Point Causeway, Lake Erie, Ontario. The Canadian Field-Naturalist, 110, 403-412.

[16] Carr, L.W. and Fahrig, L. (2001) Effect of Road Traffic on Two Amphibian Species of Different Vagility. Conservation Biology, 15, 1071-1078. http://dx.doi.org/10.1046/j.1523-1739.2001.0150041071.x

[17] Findlay, C.S. and Lenton, J. (2001) Land-Use Correlates of Anuran Community Richness and Composition in Southeastern Ontario Wetlands. Ecoscience, 8, 336-343.

[18] Hels, T. and Buchwald, E. (2001) The Effect of Road Kills on Amphibian Populations. Biological Conservation, 99, 331-340. http://dx.doi.org/10.1016/S0006-3207(00)00215-9

[19] Bradford, D.F. (2005) Factors Implicated in Amphibian Population Declines in the United States. In: Lannoo, M.J., Ed., Amphibian Declines: The Conservation Status of United States Species, University of California Press, Berkeley, 915925.

[20] Gibbs, J.P. and Shriver, W.G. (2005) Can Road Mortality Limit Populations of Pool-Breeding Amphibians? Wetlands Ecology and Management, 13, 281-289. http://dx.doi.org/10.1007/s11273-004-7522-9

[21] Voyles, J., Young, S., Berger, L., Campbell, C., Voyles, W.F., Dinudom, A., Cook, D., Webb, R., Alford, R.A., Skerratt, L.F. and Speare, R. (2009) Pathogenesis of Chytridiomycosis, a Cause of Catastrophic Amphibian Declines. Science, 326, 582-585. http://dx.doi.org/10.1126/science.1176765

[22] US Geologic Society (2009) Amphibian Disease List in Northeast Amphibian Research and Monitoring Initiative. Patuxent Wildlife Research Center.

[23] Fisher, M.C., Garner, T.W.J. and Walker, S.F. (2009) Global Emergence of Batrachochytrium dendrobatidis and Amphibian Chytridiomycosis in Space, Time, and Host. Annual Review of Microbiology, 63, 291-310. http://dx.doi.org/10.1146/annurev.micro.091208.073435

[24] Berger, L., Speare, R., Daszak, P., Green, D.E., Cunningham, A.A., Goggin, C.L., Slocombe, R., Ragan, M.A., Hyatt, A.D., McDonald, K.R., Hines, H.B., Lips, K.R., Marantelli, G. and Parkes, H. (1998) Chytridiomycosis Causes Amphibian Mortality Associated with Population Declines in the Rain Forests of Australia and Central America. Proceedings of the National Academy of Sciences of the United States of America, 95, 9031-9036. http://dx.doi.org/10.1073/pnas.95.15.9031

[25] Bosch, J., Martínez-Solano, I. and García-París, M. (2001) Evidence of a Chytrid Fungus Infection Involved in the Decline of the Common Midwife Toad (Alytes obstetricans) in Protected Areas of Central Spain. Biological Conservation, 97, 331-337. http://dx.doi.org/10.1016/S0006-3207(00)00132-4

[26] Rohr, J.R. and Raffel, T.R. (2010) Linking Global Climate and Temperature Variability to Widespread Amphibian Declines Putatively Caused by Disease. Proceedings of the National Academy of Sciences of the United States of America, 107, 8269-8274. http://dx.doi.org/10.1073/pnas.0912883107

[27] Boyle, W.J. (2003) A Guide to Bird Finding in New Jersey, Revised and Updated. Rutgers University Press, New Brunswick.

[28] Alemu, I.J.B., Cazabon, M.N.E., Dempewolf, L., Hailey, A., Lehtinen, R.M., Mannette, R.P., Naranjit, K.T. and Roach, A.C.J. (2008) Presence of the Chytrid Fungus Batrachochytrium dendrobatidis in Populations of the Critically Endangered Frog Mannophryne olmonae in Tobago, West Indies. Ecohealth, 5, 34-39. http://dx.doi.org/10.1007/s10393-008-0154-4

[29] Annis, S.L., Dastoor, F.P., Ziel, H., Daszak, P. and Longcore, J.E. (2004) A DNA-Based Assay Identifies Batrachochytrium dendrobatidis in Amphibians. Journal of Wildlife Diseases, 40, 420-428. 
http://dx.doi.org/10.7589/0090-3558-40.3.420

[30] Schloegel, L.M., Daszak, P., Cunningham, A.A., Speare, R. and Hill, B. (2010) Two Amphibian Diseases, Chytridiomycosis and Ranaviral Disease, Are Now Globally Notifiable to the World Organization for Animal Health (OIE): An Assessment. Diseases of Aquatic Organisms, 92, 101-108. http://dx.doi.org/10.3354/dao02140

[31] Reshetnikov, A.N., Chestnut, T., Brunner, J.L., Charles, K., Nebergall, E.E. and Olson, D.H. (2014) Detection of the Emerging Amphibian Pathogens Batrachochytrium dendrobatidis and Ranavirus in Russia. Diseases of Aquatic Organisms, 110, 235-240. http://dx.doi.org/10.3354/dao02757

[32] Kirshtein, J.D., Anderson, C.W., Wood, J.S., Longcore, J.E. and Voytek, M.A. (2007) Quantitative PCR Detection of Batrachochytrium dendrobatidis DNA from Sediments and Water. Diseases of Aquatic Organisms, 77, 11-15. http://dx.doi.org/10.3354/dao01831 
Scientific Research Publishing (SCIRP) is one of the largest Open Access journal publishers. It is currently publishing more than 200 open access, online, peer-reviewed journals covering a wide range of academic disciplines. SCIRP serves the worldwide academic communities and contributes to the progress and application of science with its publication.

Other selected journals from SCIRP are listed as below. Submit your manuscript to us via either submit@scirp.org or Online Submission Portal.
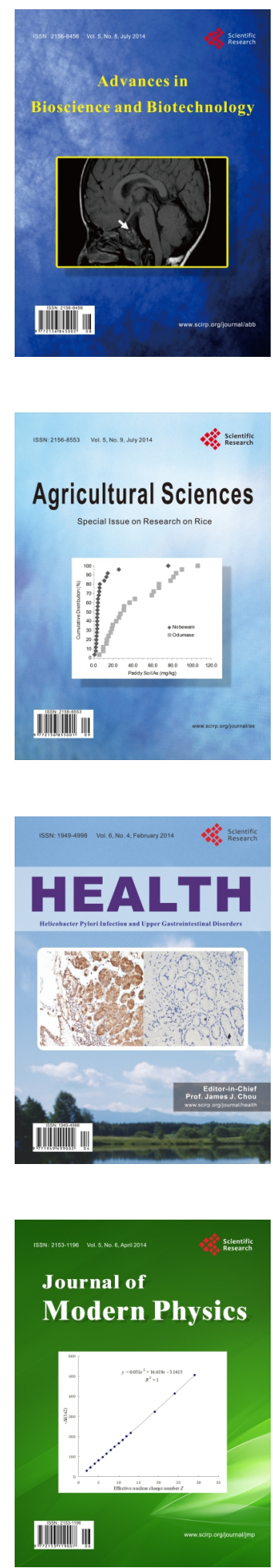
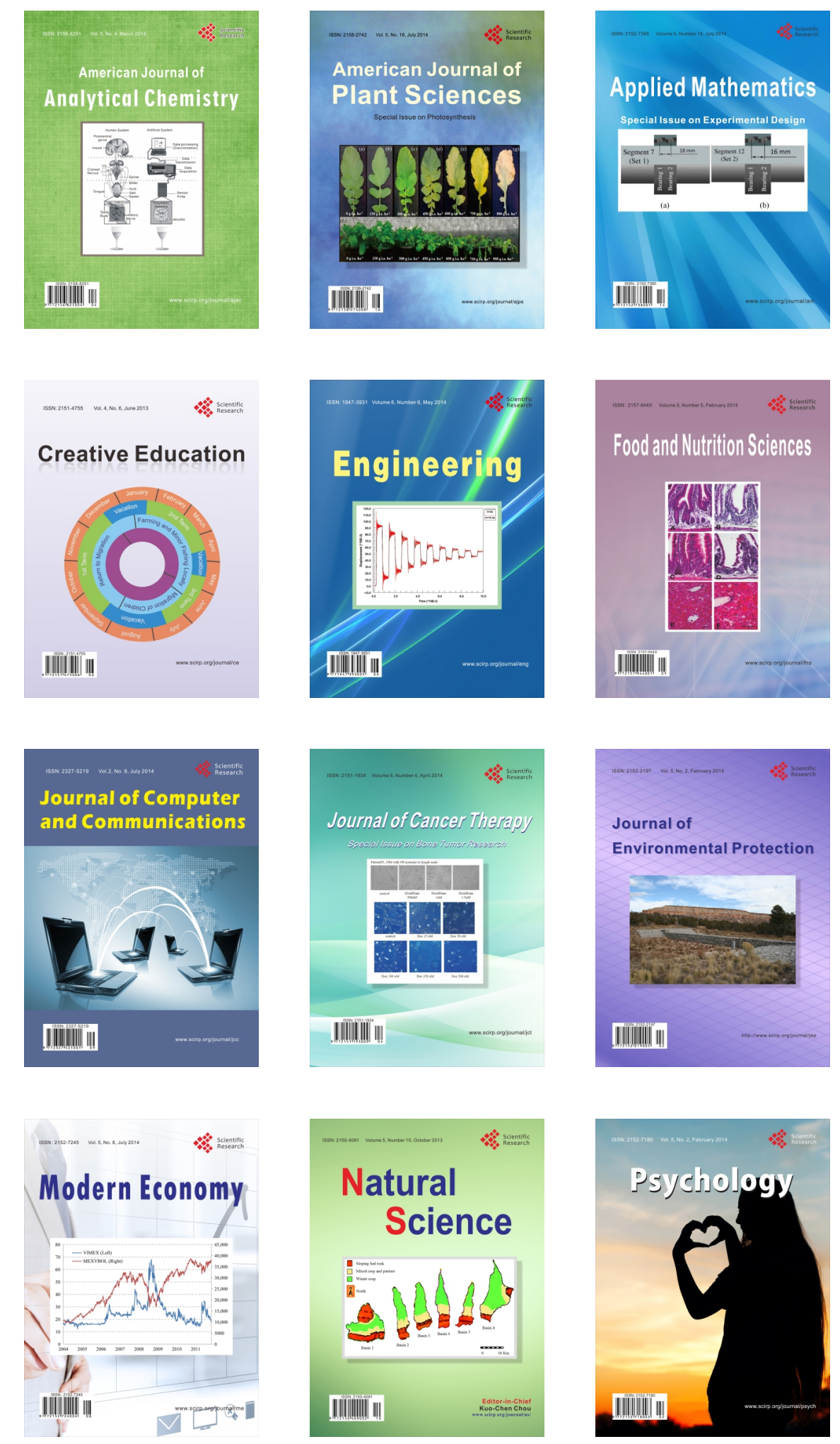